\title{
The Significance of the Black Stool as an Educational Resource in Akan Traditional Patterns of Learning
}

\author{
Kwabena Opuni-Frimpong ${ }^{1}$ \\ ${ }^{1}$ Department of Religious Studies, Kwame Nkrumah University of Science and Technology, Kumasi-Ghana.
}

\begin{abstract}
The Black Stool has been considered by Western missionaries and missionary established churches mainly as a sacred object and religious material for rituals without much attention to its educational significance. The Western missionaries introduced Christian education and schooling pattern of learning to the Akan societies. The introduction of Western and Christian education came with Bibles, Hymn Books, Liturgy books and other educational materials. Even though the Akan had their own forms of learning, the indigenous educational resources did not attract the consideration of the missionaries. The missionary legacy of not recognizing the indigenous educational materials such as the Black Stool has remained with Christian education in Akan churches and other educational patterns. The study is an examination of the educational dimensions of the Black Stool and its significance for moral and leadership formation. Using both primary and secondary sources to examine the role of the Black Stool in moral education and leadership formation, the study points out the fact that the Black Stool is capable of providing even education in Christian history and calls for the need for re-thinking Akan Christian history to reflect significant intellectual weight embedded in the Black Stool. The study has established that the Akan Black Stool that over the years has been considered mainly from its sacred and religious dimensions has educational dimensions that equally must attract intellectual attention. The study identifies the traditional pattern of learning as a discipline that must attract intellectual attention. Moreover, there is a need for a paradigm shift on the perception of the Black Stool. A paradigm shift on the perception of indigenous educational resources will position the Black Stool as a relevant educational resource for a traditional pattern of learning. The study calls for a need for re-thinking of Akan Christian history to retrieve Christian information and history that have been embedded in indigenous resources like the Black Stool.
\end{abstract}

Keywords: Akan, Black Stool, Traditional Patterns of Learning, Christianity, Educational Resources.

\section{INTRODUCTION}

The Black Stool has been considered by Western missionaries and missionary established churches mainly as a sacred object and religious material for rituals without much attention to its educational significance. The Western missionaries introduced Christian education and schooling pattern of learning to the Akan societies. The introduction of Western and Christian education came with Bibles, Hymn Books, Liturgy books and other educational materials. Even though the Akan had their own forms of learning, the indigenous educational 
resources did not attract the consideration of the missionaries. The missionary legacy of not recognizing the indigenous educational materials such as the Black Stool has remained with Christian education in Akan churches and other educational patterns.

The Black Stool and other royal stools like the Golden Stool and the Silver Stool have been identified as major educational resources for the leadership formation of Akan traditional leaders. The Akan traditional pattern of documentation of historical events is made up of objects like wooden stool blackened with soot, yolks of eggs, and blood. The use of blood has been argued more for the preservation of the wooden object more than making it a sacred object for worship. The indigenous symbol of documentation has been recognized as chapters in Akan history. For the memory of an individual to be represented by the Black Stool, the individual concerned must demonstrate traditional values that are associated with sound traditional leadership. The use of the Black Stool in Akan traditional education has remained oral and that makes it prone to distortions. However, the frequency of the use of the traditional symbol limits the tendencies to the distortion and also provides corrective measures when misinformation occurs.

The Black Stool by its nature, represents an indigenous symbol for Akan identity, unity and continuity. It is also the symbol of Akan traditional authority and power. In all its functions, the educational role in the leadership formation of the leaders has come out stronger in this investigation. The education of Akan traditional authority and power, unity, identity and continuity of the society is pursued through the reading of Akan traditional 'books', i.e., the Black Stools. This study, therefore, seeks to examine the educational dimensions of the Black Stool and its significance for moral and leadership formation.

\section{METHODOLOGY}

The research being qualitative and using a purposive sampling approach was pursued through primary and secondary sources. The Akan Black Stools at Akuapem and Asante were studied through observation and interviews. Significant available materials on the Black Stool and the early interpreters of the interaction between the Black Stool and the Christian faith were also examined.

\section{The Black Stool and Akan Christian Conversion Experience}

The Akan Black Stool is the most important symbol in Akan traditional leadership. According to Nana Addo Dankwa III, 'the Black Stool is the most important object in the palace.' ${ }^{1}$ The importance of the Black Stool however, has been considered from its sacred and religious functions without much attention to its educational functions especially during the Adae celebrations. The Black Stool has remained the main symbol for the celebration of the Adae festival. In his explanation of the Adae festival, Kofi A. Busia noted that, 'Adae refers to those ceremonies at which the spirits of departed rulers of the clan are propitiated, their names and deeds recalled, and favours and mercy solicited.' 2 He further argues that the Adae festival provides an opportunity for the people to receive prosperity and protection from their ancestors. Busia noted that 'every twenty-one days, an Ashanti ruler offers libations to his royal ancestors on behalf of his subjects, praying that the soil may be fruitful and the tribe of its increase. ${ }^{3}$ Busia does affirm the religious functions of the Black Stool.

The indigenous symbols of authority must be considered primarily as an educational resource that facilitates teaching and learning during the Adae celebration. ${ }^{4}$ Akan traditional leadership formation involves the acquisition of knowledge in history, governance, diplomacy, legal system and spirituality. Education in such areas does require resources for effective leadership formation. The major function of the Black Stool in the traditional leadership formation is for educational purposes. According to Nana Addo Dankwa III, 'since the Black Stool constitutes the history books of the periods of reign of the chiefs whose memories the stool represents, when a chief goes to the stool house during the Adae festival period, the court historians take the opportunity to narrate to the chief the good deeds of the past chiefs, whose memories have been preserved with Black Stools. The idea is to enable the living chief to learn about and emulate the good deeds of the noble

\footnotetext{
Nana Addo Dankwa III, The Institution of Chieftaincy in Ghana - The Future (Accra: Konrad Adenauer Foundation 2004$), 67$.

2 Kofi A. Busia, The Position of the Chief in the Modern Political System of Ashanti, (Oxford: Oxford University Press, 1951), 271.

3 Busia, Position of the Chief in the Modern Political System of Ashanti, 28.

4 Dankwa, The Institution of Chieftaincy in Ghana - The Future.
} 
ancestors.' 5

Nana Addo Dankwa III has indicated that traditional symbols such as Black Stools are traditional educational resources among the Akan people that are used in educating theology, religion, history, governance and ethics. Akan traditional symbols are educational resources. He argues that, 'our forefathers, who at their time had not developed the art of writing and recording events, gave special significance to their culture and rituals by using such sculptural items as stools, dolls, etc. as symbols which were made to represent various important historical events. In effect, these special sculptural items became their books in which were embedded their early history, practices and experiences for posterity.' 6

The traditional symbols predated the arrival of western missionaries. Missionaries who worked among the Akan however, viewed the Black Stool and other traditional educational materials from the prevailing arrangements that existed back at home in Europe. The educational significance of the Black Stool was not considered by the missionaries. The sacred and religious roles were also rejected as un-Christian. The inferiority and rejection of Akan cultural values were not as a result of any purposeful study but as indicated by Kwame Bediako, a European Value setting for non-Europeans. ${ }^{7}$

The Christian Council of Gold Coast, now Ghana organized a meeting in 1955 to consider responses to the challenges between African Culture and the Christian Faith. During the meeting, Busia called for a deeper consideration to be paid to the Black Stool and its contributions to the Christian faith. Busia raised the subject of the chieftaincy institution and its connection with the future of the church in Ghana. In defending the fact that Christianity can touch the whole of Akan life through the chieftaincy institution, he further pointed out to the Black Stool, as a key traditional leadership material that must be engaged in the effort to understand Akan traditional patterns of learning. Busia stated, 'I think it true to suggest that for the Akan, the stool is the symbol, par excellence, of his future. This is why I threw the challenge, which I throw again that the question of the place of chieftaincy in the Christian church of the Gold Coast is important and urgent, if Christianity is to touch the whole of our group life. ${ }^{8}$ The Akan on their interaction with Western missionaries did not have Western educational resources. At the time, the Akan had their own traditional patterns of learning which were different from the book culture that the Europeans presented.

Paolo Freire argues that the pre-existing knowledge that students bring into the learning process must be respected and allowed to function as the foundation that the teachers build upon. ${ }^{9}$ The students must be helped to appreciate the fact that they have learnt a lot from the environment before their encounter with their teachers. According to Freire, 'almost never do they realize that they, too, "know things" they have learnt in their relations with the world and other women and men. ${ }^{10}$

\section{The Black Stool as an Educational Resource}

Knowledge and values in African religions have remained in oral tradition. ${ }^{11}$ Those who know and can interpret traditional symbols, proverbs and institutions, are able to understand the belief and knowledge systems. In a sense, African indigenous knowledge systems lack Western learning materials and resources. The lack of Western learning materials does not justify the denial of cultural values because the adherents have their own approach to learning. Kwame Gyekye a leading African philosopher has argued that the absence of book culture in African does not provide the justification for the rejection of Africa philosophical thought in matters of faith, politics, environment etc. For Gyekye, 'there is no good reason to suppose that the lack of written sources implies the absence of philosophical thinking. ${ }^{12}$

In his reflections on indigenous knowledge systems, Gyekye has observed that there are adequate reasons to appreciate the weight in Akan cultural values. He argues that, 'to deny African people's philosophical

5 Dankwa, The Institution of chieftaincy in Ghana-The Future, 73

6 Dankwa, The Institution of Chieftaincy in Ghana - The Future, 72.

Kwame Bediako, Theology and Identity, (Oxford: Regnum Books 1992).

8 Kofi A. Busia, 'Ancestor worship, libation, stools, festivals'in: S.G. Williamson (ed) Christianity and African Culture, (Accra: Christian Council of Gold Coast, 1955), 22.

9 Paulo Freire, Pedagogy of the Oppressed (New York: Continuum, 1997).

10 Freire, Pedagogy of the Oppressed, 45.

11 Kwame Gyekye, African Cultural Values, (Accra: Sankofa Publishing Company 1996).

12 Gyekye. African Cultural Values, xi. 
thought is to imply that they are unable to reflect on or conceptualize their experience.' ${ }^{13}$

Affirmation of Gyekye's position on the ability of indigenous people to develop their knowledge systems, suggests that the Akan symbols and concepts on theology and education are intellectually potent enough to point to the legitimacy of African indigenous knowledge systems. The legitimacy of indigenous knowledge systems through conceptual schemes can be understood and accepted. He further affirms that, "it is, therefore, legitimate to assume that every culture produces a philosophy, or, put differently, that there is a philosophical component to a culture's thought system.' ${ }^{14}$

The educational values in the Black Stool exist in the oral tradition. It must be noted that the knowledge could as well be transmitted into writing. Gyekye argues that oral information can be written. 'African philosophical ideas are not to be found in documents, for traditional African philosophy is not a written philosophy, although this does not mean that it cannot be written down. Such ideas were embodied in proverbs, aphorisms, or fragments (as such pithy philosophical sayings are called in the context of preSocratic Greek philosophy)'. ${ }^{15}$

African traditional symbols are embedded with the intellectual weight of the people. For Gyekye, 'African philosophical thought is expressed both in the oral literature and in the thoughts and actions of the people. Thus, a great deal of philosophical material is embedded in the proverbs, myths and folktales, folk songs, rituals, beliefs, customs, and traditions of the people, in their art, symbols and in their socio-political institutions and practices.' ${ }^{16}$

Nana Addo Dankwa III affirms that the Akan Black Stool is a learning material and a very significant educational resource that has assisted the teaching and learning of the relevant information of the people. The regular interaction with such traditional symbols of authority and power creates the moments and opportunities for moral, historical, political, ethical as well as theological education. He therefore indicates, 'as the Black Stools constitute the history books of the periods of reign of the chiefs whose memories the stools represent when a chief goes to the stool house during the Adae festival period, the court historians take the opportunity to narrate to the chief the good deeds of the past chiefs, whose memories have been preserved with Black Stools. The idea is to enable the living chief to learn about and emulate the good deeds of the noble.' ${ }^{17}$

\section{Western Missionaries and the Black Stool}

Western missionaries attempted to convince early Akan converts that the Christian faith opposes the Akan cultural worldview. They did not, therefore, pursue the integration of cultural values into the transmission and education of the Christian faith. In explaining the lack of integration, Noel Smith noted that, 'wherever the missionaries worked they opposed, often successfully, those features of Akan religion and custom which were most objectionable to them, and in so doing, they aroused the conviction in the native mind that Christianity was entirely opposed to the ancestral ways. ${ }^{18}$

The belief in personal devotion to Christ did not encourage Akan belief in intermediaries like the ancestors. Moreover, the cultural values of European missionaries contributed to the lack of integration. The missionaries considered European cultures, technology and civilization as superior. Akan traditional worldview like other West African cultures was considered backward as compared to that of existing European cultures. Smith observed that, "the missionaries came from western Europe conscious at that time of its developing technology and of its cultural achievements in contrast to which West Africa could only seem backward and in dire need not only of the grace of the Gospel of Christ but also of the blessing of Christian civilization. ${ }^{19}$

Western missionaries did not consider pursuing integration because the indigenous religious practices were considered heathen, the best that could be done was to do away with such practices. Missionaries saw their task as calling the Akan into new life. Williamson noted that, 'the missionary's attitude was, without

\footnotetext{
${ }^{13}$ Gyekye. African Cultural Values, 8.

14 Gyekye. African Cultural Values, 10.

15 Gyekye. African Cultural Values, 10.

16 Gyekye. African Cultural Values, 13.

17 Dankwa. The Institution of Chieftaincy in Ghana - The Future, 73.

18 Noel Smith. Presbyterian Church of Ghana, 1835-1960. (Accra: Ghana University Press, 1966),87-88.

19 Smith. The Presbyterian Church of Ghana.87.
} 
doubt, unfavourable to Akan customary ways and traditional life. He understood his purpose in terms of calling the convert from traditional associations in heathen surroundings into a new way of life.' 20

Andrews Walls has opined that when the Gospel crosses cultural boundaries it adopts the cultural categories of its new environment for expression and survival. ${ }^{21}$ However, the early Western missionaries who worked among the Akan communities did not perceive the capabilities of African traditional belief systems for the disclosure of God. For Walls, 'the early missionaries had little in their theology to cause them to look for God in Africa traditional religion. ${ }^{22}$ In the effort to explain the Western missionaries' unpreparedness to use Akan cultural values for Christian translation and interpretation, Kwame Bediako has argued that the challenge was as a result of the European value setting for non-Europeans. For Bediako, 'what was observed in Africa was understood and interpreted, not in terms of Africa, but in terms of Europe, that is, of the European value-setting for the faith. ${ }^{23}$

Efforts were made in order to work towards the disintegration of Akan indigenous practices without intellectual exploration. The destruction of Akan indigenous belief systems became an integral part of missionary efforts. As Williamson observed, 'the primary task of missionaries among the Akan was the destruction of traditional superstition and the implantation of the Christian faith. ${ }^{24}$ The faiths were presented as two different religions that could not be integrated.

Akan people were called into the Christian faith not through their cultural understandings but through the European worldview. They were therefore to seek emancipation from their cultural past to endorse missionary acceptance. For Williamson then, 'it by no means follows from this that the Akan will become Christian, but only that he may seek emancipation from his traditional past to seek refuge elsewhere.' ${ }^{25}$

Salem became the missionary formation pattern to facilitate the disassociation of Akan Christians from their cultural past. He noted, 'the polity and organization, the liturgies and devotional expressions, the discipline and instruction, the total outlook derives directly from the parent missionary societies and the churches supporting them. The Christianity of the Akan area proves to be the denominational Christianity of the west. ${ }^{26}$ The learning patterns and educational materials that western missionaries presented to Akan Christians excluded indigenous learning resources like the Black Stool. The rejection however does not deny the existential fact of the cultural values and learning capabilities of the Black Stool.

\section{The Nature Of Akan Black Stool}

Akan worldview is dominated by traditional symbols. The Black Stool has remained over the years as one of the significant Akan traditional symbols. According to Nana Addo Dankwa III, 'the Black Stool is the most important object in the palace. It is, in most cases, rarely on display in public. ${ }^{27} \mathrm{He}$ indicates that the indigenous authority object, 'represents the authority of the chief, embodiment of the soul of the nation and the unity of the people'. ${ }^{28}$

The Black Stool moreover represents Akan indigenous symbol of authority. Akan traditional leadership is identified by those who are in possession of the Black Stool. 'The handing over of the Black Stool to an individual royal is the Akan people's way of authenticating the office of a leader. ${ }^{29}$ Recognition of leadership position is given to an individual only when the kingmakers present the Black Stool to such a person. The Black Stool is the indigenous authority symbol that authenticates authority and power of office. The Black Stool has been observed by Busia to have other functions in Akan leadership and political system apart from

\footnotetext{
20 Williamson. Akan Religion and the Christian Faith,56.

${ }^{21}$ Andrew Walls. The Cross-Cultural Process in Christian History (New York: Orbis Books, 2002).

${ }^{22}$ Walls. The Cross-Cultural Process in Christian History, 120.

${ }^{23}$ Kwame Bediako. Theology and Identity The impact of culture upon Christian thought in the second century and modern Africa. (Oxford: Regnum Books, 1992), 235.

24 Williamson. Akan Religion and the Christian Faith, 54.

25 Williamson. Akan Religion and the Christian Faith,134.

26 Williamson. Akan Religion and the Christian Faith, 165.

27 Dankwa. The Institution of Chieftaincy in Ghana - The Future p.67.

${ }^{28}$ Interview with Nana Addo Dankwa, November 22, 2004 Akropong Akuapem.

${ }^{29}$ Kwabena Opuni-Frimpong, "The Akan Traditional Leadership Formation: Some Lessons for Christian Leadership Formation" E-Journal of Humanities, Arts and Social Sciences 2, no.7 (2021): 75-91 https://doi.org/10.38159/ehass.2021272
} 
serving as a symbol of leadership office. ${ }^{30}$

In his submission at the Christian Council of Ghana meeting, he argued that the Black Stool demonstrates the very uniqueness of the Society. He submitted that the Black Stools are more than 'symbols of political power'. The indigenous symbol was described by Komfo Anokye as the soul of the nation. 'The Black Stool as the soul of the nation indicates that the Black Stool represents the very life and values of the Akan.' ${ }^{31}$

The individual who keeps the authority symbol of the society serves as the traditional leader. The indigenous leadership symbol represents not just Akan power and authority as indicated earlier. It is the representation of the cultural values and identity of the society. According to Busia, 'they symbolize a people's identity, unity and continuity, and it is these sentiments that are kept alive by the festivals and rites associated with them. This is the reason why they are dear to the Akan.' ${ }^{32}$

The association of the Indigenous authority symbol to matters of identity, continuity and unity, points to the fact that the values, morality and knowledge of the people can be appreciated by intellectual attention to the Black Stool. Connecting the Black Stool to Akan identity, Busia, therefore, was suggesting that adequate knowledge of the Black Stool determines an understanding about Akan people, their cultural values and history.

The importance of the Black Stool is seen as a rallying symbol for the society. In the olden days, the people were called to fight to protect the Black Stool from their enemies. ${ }^{33}$ The celebrations of the society are done when stories have been recollected through the Black Stool. The Black Stool becomes the symbol of celebrations during festivals. ${ }^{34}$

The Black Stool and the kingship institution have remained a key Akan institution of unity. People with different political, religious and professional affiliations rally together around the Black Stool and what they represent. The Black Stool also shapes the lifestyle even of the unborn generation as they are expected to determine their values from the deeds of their ancestors. ${ }^{35}$ The Black Stool determines the very future and continuity of the Akan people. Their future desires and ambitions are determined by knowledge acquired through the Black Stool.

The Black Stool is at the centre of the Adae festival celebrations. It has been considered as a source of blessing and protection from the ancestors. The sacredness of the Black Stool is noted in its role during the Adae festivals. According to Busia, 'Adae refers to those ceremonies at which the spirits of departed rulers of the clan are propitiated, their names and deeds recalled, and favours and mercy solicited. ${ }^{36}$

The importance of the Black Stool is moreover, linked with the kind of information that it represents. It is the indigenous symbol that preserves the information of the deeds and achievements of former leaders. The Black Stool has remained a major symbol in the leadership formation of Akan traditional leaders. ${ }^{37} \mathrm{He}$ argues that it is the indigenous literature of the society. For Nana Addo Dankwa III the Black Stool 'is the literature that we have.' 38 Tracing the rationale behind the Black Stool he noted that, the Black Stool came about due to the need of recording historical events. He opined that, 'there was a time that we did not have a means of recording history and our ancestors used all sorts of things to represent historical events, the stools, the dolls and special stones. The long and short of the whole thing is that the basic means of educating our people are the symbols that we use and the major one is the Black Stools. ${ }^{39}$

The Black Stool is a traditional resource that facilitates documentation and education in Akan traditional knowledge and values during the process of leadership formation. To the people who are outside the palace, what Nana Addo Dankwa III argues as 'book' may appear strange, as not many people have been trained to read such traditional educational resources. Nevertheless, Nana Addo Dankwa III seems to suggest

\footnotetext{
30 Busia. The Position of the Chief in the Modern Political System of Ashanti.

31 Opuni-Frimpong, "The Akan Traditional Leadership Formation,75-91.

32 Busia. 'Ancestor worship, libation, stools, festivals in Christianity and African Culture, 22.

33 Interview with Nana Addo Dankwa November 22, 2004 Akropong.

34 Interview with Nana Addo Dankwa November 22, 2004 Akropong.

35 Interview with Nana Owusu Afriyie June 2, 2004 Asante Mampong .

36 Busia. The Position of the Chief in the Modern Political System of Ashanti, 271.

37 Interview with Nana Addo Dankwa November 22, 2004 Akropong.

38 Interview with Nana Addo Dankwa November 22, 2004 Akropong.

39 Interview with Nana Addo Dankwa November 22, 2004 Akropong.
} 
that some traditional scholars and experts are trained to read and interpret information from Akan indigenous intellectual resources.

\section{The Process of Blackening Black Stools}

The Black Stool is an Akan indigenous symbol of documentation of information about traditional leaders. ${ }^{40}$ Any Akan person may keep a stool in their home. However, the stools that traditional leaders keep become the objects that are needed for the indigenous documentation material. The wooden stool after the death of its original owner is blackened with blood, the yolks of eggs and soot for it to assume its black colour. ${ }^{31}$

The blackening of the stools is the preserve of traditional leaders whose leadership and achievements are considered desirable and worth preserving. Not all traditional leaders have their stools blackened according to Okyeame Ampratwum. A stool is kept for individual traditional leaders. The number of acceptable leaders determines the number of Black Stools that a community may possess. ${ }^{42}$

Even though the Black Stools preserve the information about the community, it is not made available to the public. Nana Addo Dankwa III explains that the purpose of keeping the indigenous leadership symbol away from the public is mainly for security reasons and not any religious reasons as sometimes speculated. ${ }^{, 43}$

\section{Qualifications and Conditions for Blackening Stools}

Black Stools have been observed as an Akan indigenous approach to the documentation of significant historical events. The Akan people however, do not document every event, especially of their leaders. They are selective when it comes to the documentation of events for future education. Among the traditional leaders, an individual must qualify for their stools to undergo the process of consecration and preservation. A blackened stool, therefore, is on the assumption that the pattern of life of the leader concerned has become acceptable for emulation. ${ }^{44}$ But what are the values that the selection processes consider?

The categories of leaders whose stools are blackened involved the founders of communities and those who are able to establish themselves as desirable traditional leaders. ${ }^{45}$ The Black Stool of the founder of the community is the first one that is normally preserved. They are considered to be the originators whose exemplary lives others would want to emulate. Subsequent leaders are required to establish their relationship with the first Black Stool in order to qualify to be considered to rule. ${ }^{46}$

The community traces its history, legal framework, ethics, governance and spirituality to the leaders whose leadership patterns have become acceptable and therefore their memories are documented in the Black Stools. The original Black Stool 'represents the founder of the state, whose leadership the various families in the community have accepted. In fact, in the political sense, the Black Stool is a symbol of both unity and authority and, indeed, a contract document and a history book. ${ }^{47}$

The original stool is accepted by the community as the Black Stool of the founder of the community. However, the subsequent Black Stools are accepted due to evidence of good governance and sound morals. ${ }^{48}$ The royal families need to satisfy themselves with the achievements of desirable values before they add other Black Stools to that of the founder. The living community needs the memories of the ancestors in defining their own identity and direction. ${ }^{49}$ As Akan concept of community includes the dead, the living as well as the unborn, the disconnection of the living from the dead becomes tantamount to the extinction of history and identity, a situation that Akan people could not tolerate. ${ }^{50}$ The careful selection of individual leaders for the blackening process is to maintain a desirable identity.

\footnotetext{
40 Interview with Nana Addo Dankwa November 22, 2004 Akropong Akuapem.

41 Interview with Okyeame Ampratwum June 1, 2004 Asante Mampong.

42 Interview with Okyeame Ampratwum June 1, 2004 Asante Mampong.

43 Interview with Nana Addo Dankwa November 22, 2004 Akropong Akuapem.

44 Interview with Emily Akuffo May 14, 2004 Akropong Akuapem.

45 Interview with Addo-Fening June 6, 2004 Legon Accra.

46 Interview with Nana Addo Dankwa November 22, 2004 Akropong Akuapem.

47 Nana Addo Dankwa III. The Institution of chieftaincy in Ghana-The Future, 67.

48 Interview with Nana Addo Dankwa November 22, 2004 Akropong Akuapem.

49 Interview with Addo-Fening June 6, 2004 Legon Accra.

50 Interview with Nana Owusu Afriyie June 2, 2004 Asante Mampong.
} 
There are some deaths the Akan consider as good death. The leaders, who qualify for their wooden stools to be blackened moreover, must have evidence of good death. One such good death is death at a ripe old age. The wooden stool of a traditional leader who commits suicide, or died of illness such as madness, leprosy is not considered for preservation. If a leader runs away from his enemies during wars and in the process, he is killed, his wooden stool would not be considered for blackening. ${ }^{51}$ Moreover, those who were dis-stooled due to undesirable behaviour forfeit the benefit of having their wooden stools consecrated and preserved.

Akan communities set moral standards for their leaders. ${ }^{52}$ Busia has identified some of the desirable qualities that an Asante traditional leader must demonstrate. According to him, 'the necessary qualities were intelligence (adwenpa), humility (ahobrease), generosity (ne yam ye), manliness (abooduru), and physical fitness (dem biara nni ne ho). ${ }^{53}$ Similarly, Nana Addo Dankwa III has identified moral values that Akuapem traditional leaders must demonstrate. According to him 'the moral values that attract the consideration for the selection of wooden stools for the blackening process include, 'exhibition of intelligence, hard work, humility, generosity, courage, self-control, and chastity. They must also demonstrate respect for elders, both living and dead. ${ }^{54}$

Traditional leaders are made aware of these moral values even before their nomination for enstoolment. If the leaders are able to live the desirable moral lives, they are considered to be a pride to the community and example for emulation by later generations and leaders. ${ }^{55}$ The leaders whose wooden stools are blackened are also considered by the contributions they make towards the growth and development of the community. ${ }^{56}$ Their names and deeds are therefore preserved through the consecration and preservation of their wooden stools for keeping in the black stool room.

If even a leader dies while in leadership but did not live an upright life, their stools are not considered for preservation and remembrance. Their wooden stools are kept outside the Black Stool room as a deterrent to future generations. ${ }^{57}$ Apart from the Black Stools, there are other Royal Stools that only a few Asante traditional leaders can keep. They include the Golden Stool and the Silver Stool of Asante.

\section{The Golden and Silver Stools}

Akan stools are normally black in colour. However, there are two significant stools that are used for the same purpose but with different colours and status. ${ }^{58}$ The most prominent and greatest sacred stool among Asante stools is the Sikadwa (Golden Stool). The Golden Stool enshrines the soul of Asanteman (Asante kingdom). According to Okyeame Ampratwum 'among all the wonders that Okomfo Anokye performed in Asanteman, the Golden Stool has been noted as the most very significant. ${ }^{59}$

The next in importance to the Golden Stool is the Dwete Dwa (Silver stool), which the Asante Mamponghene occupies. ${ }^{60}$ Okomfo Anokye who constructed it decreed that the occupant of the Silver Stool at any time must be second to the Asantehene. In the absence of Asantehene either through death, destoolment or abdication, Mamponghene assumes immediate leadership of Asanteman. ${ }^{61} \mathrm{He}$ is to supervise the enstoolment process of a new Asantehene and hand over to him the Golden stool and leadership of Asanteman. It has been observed that the various Akan Royal Stools i.e., the Black Stools, the Silver Stool and the Golden Stool facilitate leadership formation. ${ }^{62}$

\footnotetext{
51 Interview with Nana Addo Dankwa November 22, 2004 Akropong Akuapem

52 Busia. The Position of the Chief in the Modern Political System of Ashanti,9.

53 Busia. The Position of the Chief in the Modern Political System of Ashanti,9.

54 Interview with Nana Addo Dankwa November 22, 2004 Akropong Akuapem

55 Interview with Mercy Amba Oduyoye May14, 2004 Legon Accra.

56 Interview with Sam Prempeh September 1, 2004 Osu Accra.

57 Interview with Sam Prempeh September 1, 2004 Osu Accra.

58 Interview with Okyeame Ampratwum June 1, 2004 Asante Mampong.

59 Interview with Okyeame Ampratwum June 1, 2004 Asante Mampong.

${ }^{60}$ Interview with Okyeame Ampratwum June 1, 2004 Asante Mampong.

${ }^{61}$ Interview with Okyeame Ampratwum June 1, 2004 Asante Mampong.

${ }^{62}$ Interview with Nana Owusu Afriyie June 2, 2004 Asante Mampong.
} 


\section{Black Stools, Adae Festivals and Leadership Formation}

The Adae festival and the nomination of royals for consideration for enstoolment have been identified as the moments that the Black Stools are used for the traditional leadership formation. The Adae literally is translated as a bedroom or resting place. Akan people believe that the older a person becomes the more they assume the status of wisdom and maturity. ${ }^{63}$ Those who seek wisdom and knowledge from such elderly members of the society are therefore advised to visit them Adae in their resting places for education. ${ }^{64}$ Adae celebration has remained one of the celebrations that is commonly recognized in Akan societies. The Adae celebration gives the people the opportunity to get closer to their ancestors. During the Adae celebration, it is assumed that the ancestors are resting in their bedrooms. The royals and traditional leaders in their desire to acquire wisdom and knowledge get closer to them at every Adae celebration to benefit from the accumulated knowledge of the ancestors. ${ }^{65}$

Nana Addo Dankwa III argues that the primary motive for the regular visitations to the Black Stool room is educational and not so much spiritual as to offer the ancestors worship. He considers the notion of feeding the ancestors on the festivals as just symbolic of their fellowship with the living. He argued in an interview that, 'it is not true that the ancestors eat. It is not biologically correct. They are dead and gone but their memories should be preserved so that we would be able to learn about them when we go to the Black Stool room during the Adae period.' ${ }^{66}$

The Black Stools are supposed to be the ancient chiefs who are in their bedrooms who are either resting or sleeping. 'Whenever you want to know about the secrets behind their successes you go to them. That is the reason why their memories have been preserved for the living to follow in their footsteps in order to be remembered in the future. You go there and the stool historians narrate to you the history of each stool. ${ }^{67}$ The Adae then is the celebration of the memories of the ancestors. New leaders are key benefactors of the Black Stool room education. The stool historians who are the main agents of nurture are the head of the stool carriers. In the stool room, they narrate to their learners the history of each stool. The frequent visit of traditional rulers to the Black Stool room should be seen as classroom participation in history lessons. ${ }^{68}$

The Akan stool historians, therefore, use the Black Stools to inform the people of the good deeds of their great leaders. The agents of traditional education who use the traditional patterns of learning resources such as Black Stools have proved themselves as good historians over the years. They actually attract sanctions if they do not handle the lessons with the accuracy it deserves. Okyeame Ampratwum who has been in the Black Stool room history education for 35 years said he always tries to avoid possible mistakes because if he does so, he will be reprimanded. ${ }^{69}$ The continuous celebrations of the Adae have contributed towards the preservation of Akan cherished memories and leadership values.

\section{Choosing Royal Stool Names}

Royals who are selected to occupy Akan leadership positions are required to adopt royal stool names (Nkwonnwadin). The names that they adopt are made public during the installation process. Otumfuo Osei Tutu II, for instance, was called Kwaku Dua before his installation. ${ }^{70}$ The name that a new Akan traditional leader selects is an affirmation that he wants to identify with the moral and leadership values that the original bearer of the name demonstrated.

The choosing of royal stool names takes place in the stool house at night. There are claims that selected leaders are blindfolded during the process of selecting particular Black Stools of former rulers after whom they may want to pattern their leadership style. The assumption is that the Black Stool that would be selected in the process will be considered as divinely determined. However, there are other palace court practitioners

${ }_{63}$ Interview with Nana Addo Dankwa III November 22, 2004 Akropong Akuapem.

${ }^{64}$ Interview with Nana Addo Dankwa III November 22, 2004 Akropong Akuapem.

65 Interview with Nana Addo Dankwa III November 22, 2004 Akropong Akuapem.

${ }_{66}$ Interview with Nana Addo Dankwa III November 22, 2004 Akropong Akuapem.

${ }^{67}$ Interview with Nana Addo Dankwa III November 22, 2004 Akropong Akuapem.

${ }^{68}$ Interview with Nana Addo Dankwa III November 22, 2004 Akropong Akuapem.

69 Interview with Okyeame Ampratwum June 1, 2004 Asante Mampong.

${ }^{70}$ Irene Odotei, and George Hagan, The King Returns: Enstoolment of Asantehene Osei Tutu II. (Accra: Institute of African Studies, 2002). 
who reject the association of any form of divinity to the process of name selection. The association of divinity to the process is considered just to surround the process with some kind of mysticism. According to Bekoe, 'the impression has been created that they blindfold the kings in the stool house to choose their names. That is not fully correct. There are royal lines and each wants to maintain their lineage. There are three major lines in Akropong, the Sakyiabea, Ama Ogyaa, and Nketia. Names are chosen according to one's lineage. The blindfolding myth is just to mystify the practice. The family meets to choose the name before even they go to the stool house. The stool carriers and Akyeame do the name choosing at midnight. The society expects Ohene to emulate the lifestyle of the name of ancestors he chooses. Our traditional leadership system provides a system of education, which is un-ending. ${ }^{91}$

The rejection of the notion of divine intervention in the name selection process is to suggest that the leaders have control over the names they select. In a sense, the names are not only admired and respected but one consciously would want to uphold it as a moral standard. Nana Owusu Afriyie in providing the Asante perspective on the name selection also argued that the choice of royal stool names in the installation process is the outcome of family consultations. Nana Owusu Afriyie argued in an interview that the names are agreed upon by the families. Using his example, he stated, 'the new leaders are asked to mention their names when they are swearing the oath. My original name was James Osei Bonsu. The Gyasehene asks the family head to present the new king and mention his name. He then gives the name, which the family has already agreed on.' 72

The consultation among family members may be explained by the fact that they want to maintain their family lineage. Families may as well want to use the selection of names to attach some success to their members whom they would want to celebrate as successful traditional leaders. Nevertheless, the selected name eventually would have educational significance, as the new leader will be required to emulate the moral and leadership qualities that the name represents.

The royal stool name will maintain educational significance on the new leader as it continuously reminds him of what he has become. The Black Stools are considered as representatives of the ancestors. A name chosen is an indication that a desirable leader has come back. The bearer of such a name would be required by the larger society to emulate the desirable moral and leadership qualities. ${ }^{73}$ Failure of new leaders to demonstrate the qualities in their names will not only cause disappointments among the public but may lead eventually to destoolment. The selection of royal stool names by Akan traditional leaders among others is to serve as a mechanism in upholding moral values among traditional leaders. ${ }^{74}$

\section{Educational Significance of Black Stools}

The Akan it has been noted pay much attention to conduct and behaviour. Leadership formation therefore directs attention to history, governance, spirituality, morality, diplomacy and healthy relationships. Busia has noted that, 'the Asante have concepts of right and wrong, of acceptable and unacceptable behaviour, culturally defined in terms of their own life and belief, and as has been apparent in the belief accounts given ancestors and gods punish those who violate the intentionally sanctioned code and reward those who keep it. ${ }^{75}$

The ancestors whose deeds are preserved in the Black Stools play influential roles in the maintenance of morality. Busia has noted, 'the moral codes of African communities are indeed circumscribed in their application. They concern the individual in his relation to his lineage and clan and the life of the group. They are nevertheless moral systems. Religion along with custom and law control human conduct. The moral standards are sanctioned by the ancestors who see to it that they are observed. ${ }^{76}$

\section{Education in Akan Morality and Values}

A major concern of Akan traditional leadership institution is the morality of its leaders. The leadership

\footnotetext{
${ }^{71}$ Interview with Kwame Bekoe May 21, 2004 Akropong Akuapem.

72 Interview with Nana Owusu Afriyie June 2, 2004 Asante Mampong.

73 Interview with Nana Owusu Afriyie June 2, 2004 Asante Mampong.

74 Interview with Nana Addo Dankwa III November 22, 2004 Akropong Akuapem.

75 Busia. 'Ancestor worship, libation, stools, festivals in Christianity and African Culture', 21-22.

${ }^{76}$ Busia. 'Ancestor worship, libation, stools, festivals in Christianity and African Culture', 22.
} 
formation therefore gives much credence to moral education and the Black Stool contributes to the moral formation of traditional leaders. Nana Addo Dankwa III has argued that the belief in ancestors and the symbols like the Black Stool facilitate moral formation. He stated that, "many of the acts or rituals performed in the palaces are symbolic gestures; for instance, the cult of the ancestors is intended to encourage the living to lead lives worthy of emulation so that when the living join the ancestors, their memories also might be preserved for posterity. ${ }^{, 77}$

The practices surrounding the Black Stool are to challenge the living to pursue values and qualities that will qualify them to become ancestors and also for stools to be blackened after them. The traditional symbols give opportunity for the people around the leader who are supposed to facilitate continuous formation to have reference points in their educational roles. Nana Addo Dankwa III further states, 'the symbolic gestures of the Akan such as the reverence made to the ancestors is, in effect, intended for the living who see what is going on to give them (the living) the assurance that if they lead exemplary lives, their memories will also be revered after death' ${ }^{78}$

It must be emphasized that in order to qualify as an ancestor whose memory is to be perpetuated by a Black Stool, one has to live an exemplary life during one's lifetime..$^{79}$ The memory of such a person is very much cherished after his death and is accorded a special place among the living. In his lifetime, an ancestor should have played his role in such a manner that his life becomes an example and inspiration to posterity. It means, therefore, that it is not everybody who after death is revered as an ancestor. ${ }^{80}$

\section{Black Stools and Education of Christian History}

The documentation of Christian history in Akan society has been pursued by Christian scholars including Smith. Such Akan Christian history normally portrays Akan Christian history from the perspectives of the Western missionaries. The approach gives the impression of a lack of history from the perspective of the indigenous people. But does Akan history begin with the arrival of missionaries and the Western pattern of education?

The Western missionaries were on their arrival, welcomed by the Akan traditional leaders. They offered the missionaries portions of their lands for the construction of schools and chapels. They were, on their arrival, usually accommodated in the homes of the traditional leaders. ${ }^{81}$ Some of the traditional leaders became friends of the missionaries and partners in the missionary movements as they were closely related with the missionaries in meeting some of their basic needs. The Akan worldview gives recognition to the documentation of events. But how did they document their encounter with western Christian missionaries?

Nana Addo Dankwa III during an interview argued that the traditional leaders documented their encounter with the missionaries with traditional symbols. He again identified the Black Stool as the major symbol of the documentation of the encounter between Akan traditional leaders and western missionaries. ${ }^{82}$ If the argument of Nana Addo Dankwa III is right then the traditional leaders are in possession of part of Akan Christian history. Akan Christian history must therefore then not be studied only from the documentations by Western missionaries but must also be retrieved from indigenous documentation like the Black Stool.

\section{Akropong Christian History through the Black Stool Room and Adae Education}

Nana Addo Dankwa III used the example of the encounter between Dr. Paul Isert and Nana Obuobi Atiemo in the $18^{\text {th }}$ century and how that knowledge assisted the visit of Andreas Riis to Akropong Akuapem. He narrated the following story, which is considered very instructive. According to Nana Addo Dankwa III, Nana Addo Dankwa I was the one who gave the Basel Evangelical Missionary Society the opportunity to spread the Christian faith in Akropong. The Christian faith he argued has brought about signs of enlightenment and development to Ghana through the Akuapem acceptance of the Christian faith and early missionaries.

\footnotetext{
77 Dankwa. Institution of Chieftaincy in Ghana-The Future, 63.

78 Dankwa. Institution of Chieftaincy in Ghana- The Future, 63-64.

79 Interview with Mercy Amba Oduyoye May14, 2004 Legon Accra.

80 Dankwa. Institution of Chieftaincy in Ghana - The Future, 63-64.

${ }^{81}$ Interview with Nana Addo Dankwa III November 22, 2004 Akropong Akuapem.

${ }^{82}$ Interview with Nana Addo Dankwa III November 22, 2004 Akropong Akuapem.
} 
However, Nana Addo Dankwa I received his education about Europeans and Christian missionaries from the Black Stool room. Nana Addo Dankwa I, according to Nana Addo Dankwa III indicated, 'learnt about Europeans and missionaries through the Black Stool of Nana Obuobi Atiemo. ${ }^{83}$

In 1780, according to Nana Addo Dankwa III, Nana Obuobi Atiemo had a friend he met during the Anlo War. This man was a Danish man called Dr. Isert. Dr. Isert after the war visited his friend Nana Atiemo at Akropong. Dr. Isert, according to the Akuapem traditional history, was supposed to be the first European to have visited Akropong Akuapem. Dr. Isert was a botanist and therefore interested in environmental issues. He introduced many foreign crops and the best method of cultivating these crops. Akuapem became very prosperous and environmentally conscious. The education and demonstrations of Dr. Isert improved the image and quality of life of Akropong and other Akuapem citizens. But how did Nana Addo Dankwa I learn this lesson considering the inability of his people to document the information in books?

In 1822, according to Nana Addo Dankwa III, Nana Addo Dankwa I was installed Okuapemhene. During the installation process, he was sent to the Black Stool room to receive his lessons in traditional leadership. He was taught about Dr. Isert and his work in Akropong through the Black Stool of Nana Obuobi Atiemo. Nana Addo Dankwa I was encouraged to be hospitable and friendly with Europeans due to the environmental and economic benefits of Akuapem association with Dr. Isert.

Nana Addo Dankwa I received the education to be receptive to Europeans in general and all those who would come to his kingdom with information intended to contribute to the growth of the Akuapem state. The acceptance of missionaries of the Basel Missionary Society into the Akropong community may be explained that Akropong was the then headquarters of the Akuapem state. The reasons behind the acceptance of the missionaries to Akropong, according to Nana Addo Dankwa III, must be explained by the history lessons that Nana Addo Dankwa I received at the Black Stool room, rather than by the fact of Akropong being the headquarters of the Akuapem state.

\section{Akropong Christian History through History Books in Switzerland}

When Andreas Riis was appointed missionary to the Gold Coast, he happened to be in Switzerland. When he went back home to say goodbye to his parents, he spent some time looking around for literature on the Gold Coast and the only literature he had was Dr. Isert's dairy on his sojourn in Akropong-Akuapem. When he came to the Gold Coast, his main assignment was to teach the mulattos in the castles who had white blood in them who were wasting away without proper education and upbringing. After some few months, he decided that his main aim was to go to the interior to spread the gospel and the place he settled was at Akropong having being guided by the information he received from the dairy of Dr. Isert in Denmark.

When information was given to Nana Addo Dankwa I about the arrival of Riis, European, he was very much satisfied. When Andreas Riis finally came to Akropong, his elders were not initially in agreement with him but Nana Addo Dankwa I, went out of his way to welcome him with a durbar. He put Riis into the house of one of his elders and later on assisted Riis in putting up his own house at Akropong. ${ }^{84}$

\section{Re-Thinking Akan Christian History}

The lessons that Nana Addo Dankwa I obtained from the Black Stool room, according to Nana Addo Dankwa III, were able to help make Akuapem the cradle of not only Christianity but also education and civilization in Ghana. ${ }^{85}$ According to Nana Addo Dankwa III, the knowledge that Nana Addo Dankwa I acquired during his Black Stool room lessons made a significant contribution to the missionary success of the Basel Missionary Society in Ghana.

The account of Nana Addo Dankwa III, contributes a unique indigenous historical perspective on Akuapem and indeed Ghanaian Christian history. At the least, the account argues for paying greater attention to indigenous forms of documentation and calls for re-thinking and re-writing of Akan Christian history to incorporate Christian information embedded in indigenous intellectual resources.

\footnotetext{
83 Interview with Nana Addo Dankwa III November 22, 2004 Akropong Akuapem.

${ }^{84}$ Interview with Nana Addo Dankwa III November 22, 2004 Akropong Akuapem.

${ }^{85}$ Interview with Nana Addo Dankwa III November 22, 2004 Akropong Akuapem.
} 


\section{CONCLUSION}

The study has established that the Akan Black Stool over the years has been considered mainly from its sacred and religious dimensions has educational dimensions that equally must attract intellectual attention. The study identifies a traditional pattern of learning as an intellectual discipline that must attract attention. Moreover, there is a need for a paradigm shift on the perception of the Black Stool. A paradigm shift on the perception of indigenous educational resources will position the Black Stool as a relevant educational resource for a traditional pattern of learning. The study calls for a need for re-thinking of Akan Christian history to retrieve Christian information and history that have been embedded in indigenous resources like the Black Stool.

\section{ABOUT AUTHOR}

Kwabena Opuni-Frimpong (PhD), Lecturer in African Christianity, Department of Religious Studies, Kwame Nkrumah University of Science and Technology, Kumasi - Ghana.

\section{BIBLIOGRAPHY}

Kwame Bediako. Theology and Identity The impact of culture upon Christian thought in the second century and modern Africa. Oxford: Regnum Books, 1992.

Busia, K.A. The position of the chief in the modern political system of Ashanti, Oxford University Press, 1951. 'Ancestor worship, libation, stools, festivals'in: S.G. Williamson (ed) Christianity and African

Culture, Accra: Christian Council of Gold Coast, 1955.

Freire, Paulo. Pedagogy of the Oppressed (New York: Continuum, 1997).

Gyekye, Kwame. African Cultural Values, Accra: Sankofa Publishing Company 1996.

Nana Addo Dankwa III, The Institution of Chieftaincy in Ghana - The Future. Accra: Konrad Adenauer Foundation, 2004.

Odotei, Irene and Hagan, George. The King Returns: Enstoolment of Asantehene Osei Tutu II. Accra: Institute of African Studies, 2002.

Opuni-Frimpong, K. "The Akan Traditional Leadership Formation: Some Lessons for Christian Leadership Formation" E-Journal of Humanities, Arts and Social Sciences 2, no.7 (2021): 75-91 https://doi.org/10.38159/ehass.2021272

Smith, Noel. The Presbyterian Church of Ghana 1835-1960. Accra: Ghana University Press, 1966. Walls, Andrew. The Missionary Movement in Christian History. New York: Orbis Books, 1996. Williamson, S.G. Akan Religion and the Christian Faith, Accra: Ghana University Press, 1965. Christianity and African Culture. Accra: Christian Council of Gold Coast, 1955.

\footnotetext{
APPENDIX

Interview with Mercy Amba Oduyoye May14, 2004 Legon Accra. Interview with Emily Akuffo May 14, 2004 Akropong Akuapem. Interview with Kwabena Nketia May 19, 2004 Madina Accra. Interview with Kwame Bekoe May 21, 2004 Akropong Akuapem. Interview with Okyeame Ampratwum June 1, 2004 Asante Mampong. Interview with Nana Owusu Afriyie June 2, 2004 Asante Mampong. Interview with Nana Kwabena Safo June 3, 2004 Asante Mampong. Interview with Nana Addo Dankwa III November 22, 2004 Akropong Akuapem. Interview with Addo-Fening June 6, 2004 Legon Accra. Interview with Sam Prempeh September 1, 2004 Osu Accra.
} 